\title{
EFFECT OF SUBMERGENCE RATIO OF PILE CAP ON SCOUR HOLE AT COMPLEX BRIDGE PIERS
}

\section{Esam Eldeen Y. Helal}

\author{
Assist. Prof., Civil Engineering Dept., Faculty of Engineering, Menoufia University, Egypt.
}

\begin{abstract}
Local scour around complex bridge piers under different clear-water conditions was studied experimentally for a variety of submergence ratios, skew angles and geometric shapes. A total of one hundred and fifty six runs were carried out. Three sets of experiments were performed over the entire range of possible pile cap shapes for complex piers with five different submergence ratios and three values of skew angles ( angle of attack) of complex pier under different four values of Froude number. The collected data are used to analyze the scour hole geometry around such complex piers. Obtained results were analyzed and graphically represented. Results indicated that, increasing submergence ratios led to increase relative scour depth and length. Also increasing skew angle led to increase scour hole geometry. Although rectangular pile cap with round nose of complex pier gave the smallest scour hole dimensions, rectangular pile cap with sharp nose of complex pier gave closed results to it.

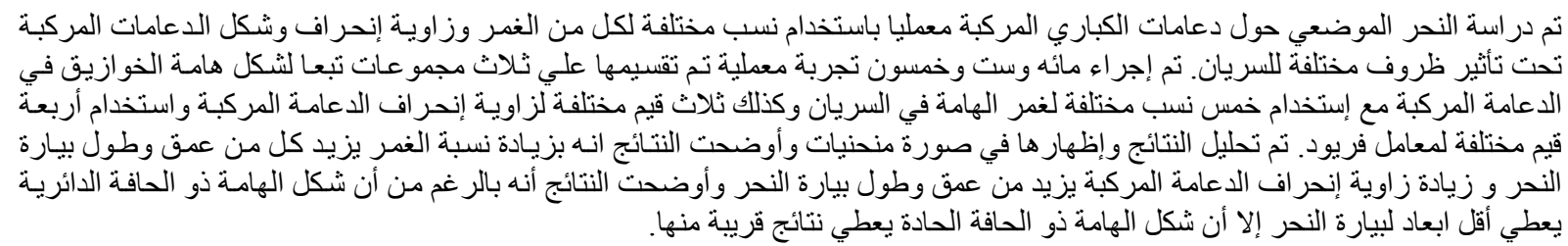

Keywords: Scour; Complex bridge pier; Skew bridge pier; Pile caps; Physical model.

\section{INTRODUCTION}

A pier column founded on a pile cap supported by an array of piles is referred to herein as complex piers. The complex piers, see Fig. (1), are constructed of several components, (i.e., column, pile cap, and pile group). Local scour at bridge complex piers is considered one of the main causes of bridge failure. Accurate predictions of the scour depth and length are crucial for the designing of bridge foundations because underestimation may lead to bridge failure and loss of life while overestimation leads to extra construction costs. Estimation of the scour depth, around bridge piers has been studied for many years. Most studies have been performed for bridge piers with a uniform cross section, Melville [11], Ettema [8], Baker [3], Melville and Sutherland [12], Dey et.al [7], Sheppard et.al [15], Coleman and Melville [5].

Scour at pile groups had been studied by many researchers, Ashtiani and Beheshti[2] investigate experimentally local scour around pile groups under steady clear-water scour condition. They studied different pile group arrangements, spacing, flow discharges, and sediment grain sizes. Hannah [10] investigated scour around pile, for different pile spacing and arrangements. Sumer et.al [16] presented the results of an experimental investigation on scour around piles exposed to waves. In addition to the actual scour tests, bed shear-stress measurements and a flow visualization study are carried out. Sumer and Fredsoe [17] study experimentally scour around a pile subject to combined waves and current. Salim and Jones [13] conducted experiments to measure local scour around exposed pile groups for a variety of conditions including different spacing, different skew angles, different patterns and different exposures of a pile cap in the flow field.

Proper scour prediction is necessary for the complex bridge piers. The United States design procedure for complex piers is summarized in $H E C$ 18 of Richardson and Davis [13]. For this procedure, it is proposed that the total scour depth is evaluated by a superposition approach, comprising a conceptual separation of the pier components, and determination (based on expressions derived from laboratory measurements) of the respective scour depths for the individual components as exposed to the flow. This approach is quite complicated, and suffers from conceptual and practical limitations. For example, if

Engineering Research Journal, Vol. 37, No.1, January 2014, PP: 123-135 
not correctly formulated, such a superposition approach might be expected to overestimate the local scour at a complex pier. Coleman [6] presented a mbines existing expressions for scouring, respectively, at uniform piers, caisson-founded piers, pile groups with debris rafts, and pile groups alone. Amini et.al [1] study experimentally local scour at pile cap. The main variables investigated were pile cap dimensions, and location relative to stream bed. According to the rate of changing in scour depth, the scour at pile cap for different cap level was divided into four cases. Equations for correction factor for these four cases are derived. Cherties et.al [4] investigated experimentally the influence of flow conditions on the shape of the scour hole for different configurations of pile groups with and without pile cap. It was found that, whenever no pile cap was present, the angle of repose of the sediment dominated the geometry of the scour hole, regardless of flow condition. On the contrary, in the presence column is not exposed to the flow. new methodology to predict local scour depth at a complex pier that co

of a pile cap, the geometry of the scour hole strongly depended on flow condition. Ferraro et.al [9] studied experimentally the effect of pile cap thickness on maximum scour depth for different complex pier configurations. They found that, the thicker the pile cap, the deeper the corresponding scour hole.

This paper presents an experimental study of local scour around complex piers under steady clearwater flow condition; this study is concerned with the presence of the pile cap of a complex bridge pier in the flow field during the lowest and highest water levels with respect to skew angles of complex pier and flow conditions. As shown in Fig. (1) and Photos (1 and 2). The effective components of the complex pier are only (the pile cap and the pile group) because the pile cap had upper edge higher than the high water level, consequently, the

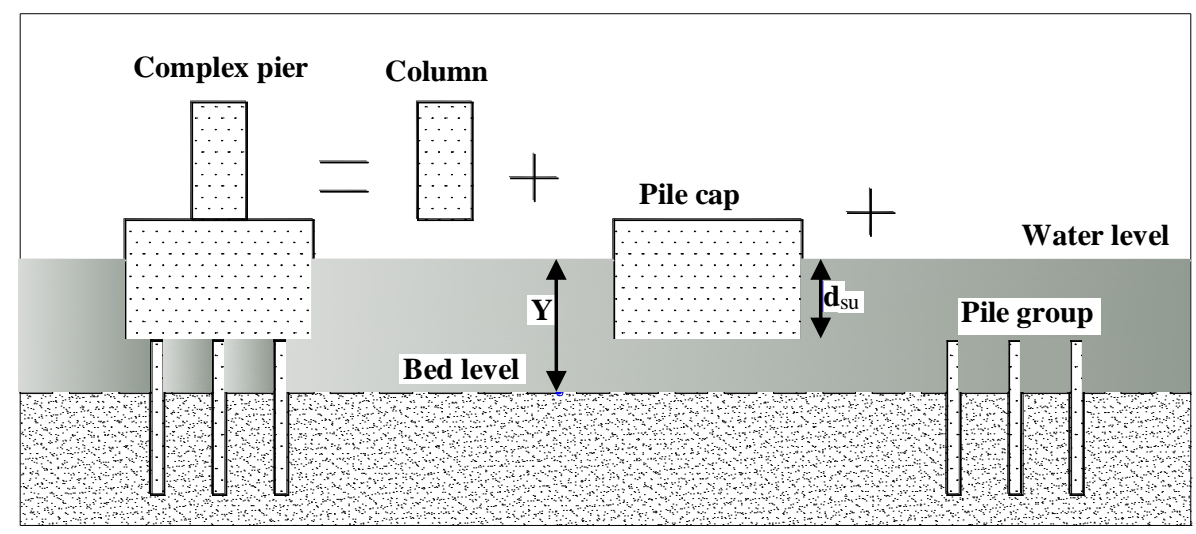

Fig (1): Component of complex pier

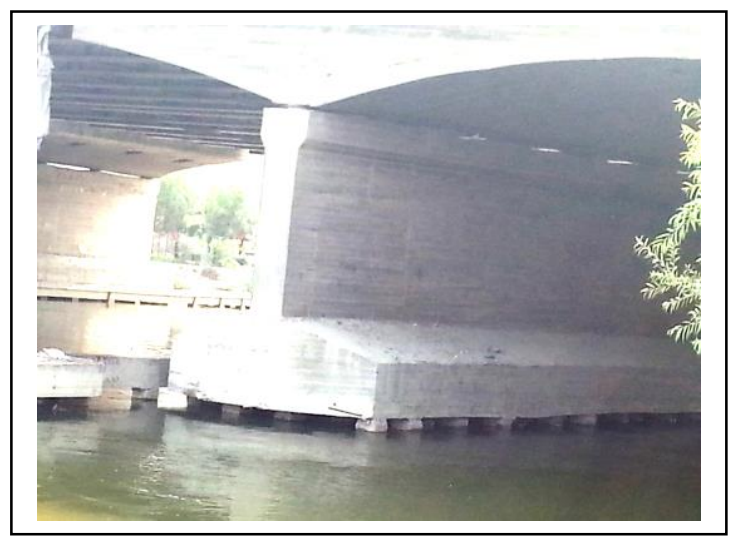

Photo (1): Mestored bridge at Cairo-Egypt

\section{PROBLEM DEFINITION}

Local scour deforms due to the removal of bed material particles around piers or pile groups. Local

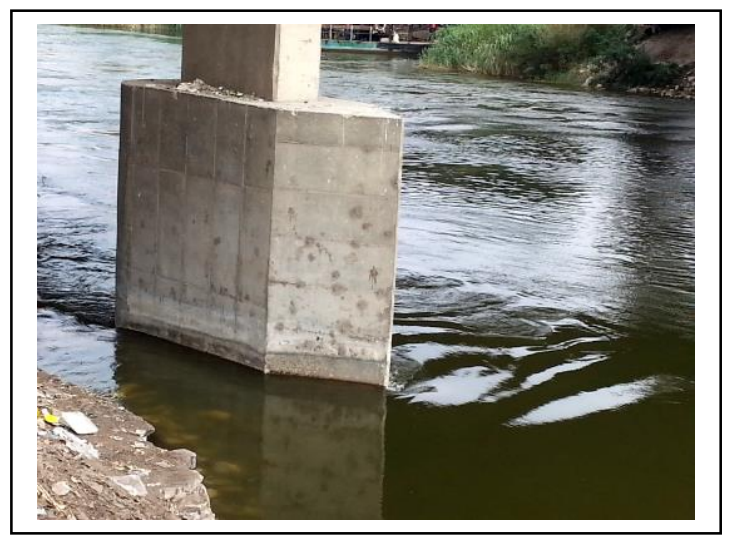

Photo (2) Mataria bridge at Cairo-Egypt

scour caused by the acceleration of the flow and the resulting vortices induced by the flow obstructions. At bridge pier site, the presence of the pier decreases 
the water cross-sectional area, consequently the velocity at the pier increases. Scouring vortices are developed when the flow of high velocity near water surface strikes the nose of the pier which is deflected towards the bed sucking the bed material particles around bridge pier. Also, the increased velocity is greater than the critical velocity of the bed material, the bed material will be eroded so that, scour hole will be deformed and scour hole dimensions will be increased. The eroded material will be transported in the downstream direction to a place where the sediment load is equal to the sediment transport capacity. The deposited material will form a mound just downstream of the scour hole. The depth and the length of the scour hole will increase with time forming a mound just downstream of the scour hole. The water depth of the flow at pier will increase consequently, average flow velocity will decrease with time while the increased water depth eliminates the effect of vortices, sequentially the rate of the scour will decrease with time till the scour ceases. At that moment the scour hole reaches equilibrium.

\section{EXPERIMENTAL SETUP}

The experimental investigations were carried out in the hydraulic laboratory of Civil Engineering Department, Menofia University, Egypt. A recirculating flume of $18 \mathrm{~m}$ long, $60 \mathrm{~cm}$ wide and 60 $\mathrm{cm}$ deep was used, see Fig. (2). Water was pumped to the head tank from ground sump. A bolder gravel box was fixed at the beginning of the flume downstream of the head tank to absorb any water eddies. Calibrated sharp crested weir was built up at the downstream end of the by-pass channel to measure the discharge passed through the channel. An adjustable tail gate controlled the water level within the flume. For measuring the water depths and bed levels at different reaches of the channel, an x-y carriage was constructed on two rails on the two sides of channel. A point gauge was fitted on the carriage and used to measure both the water levels and bed levels in the longitudinal and the crosssection directions of the channel. The point gauge can measure the depths to an accuracy of $0.1 \mathrm{~mm}$. The movable bed was simulated by a sand of mean particle size $\mathrm{D}_{50}=0.42 \mathrm{~mm}$ and standard deviation $\sigma$ $=1.9$. The grain size of the material forming the erodible bed was kept the same for all the test runs to provide a proper comparison under similar conditions. A steel model with different pile cap shapes, skew angles, submergence ratios were placed at $6.0 \mathrm{~m}$ from the upstream of the flume at the center line of the flume. A rectangular pile cap length and width were kept constant for all runs and were equal 40.0 and $12.5 \mathrm{~cm}$, respectively. Herein the blockage effect of the pier (the effect of pier width to the flume width) was neglected. The piles had square section with dimensions $2 \times 2 \mathrm{~cm}$. The distance between centerline of piles of $9 \mathrm{~cm}$ was kept constant

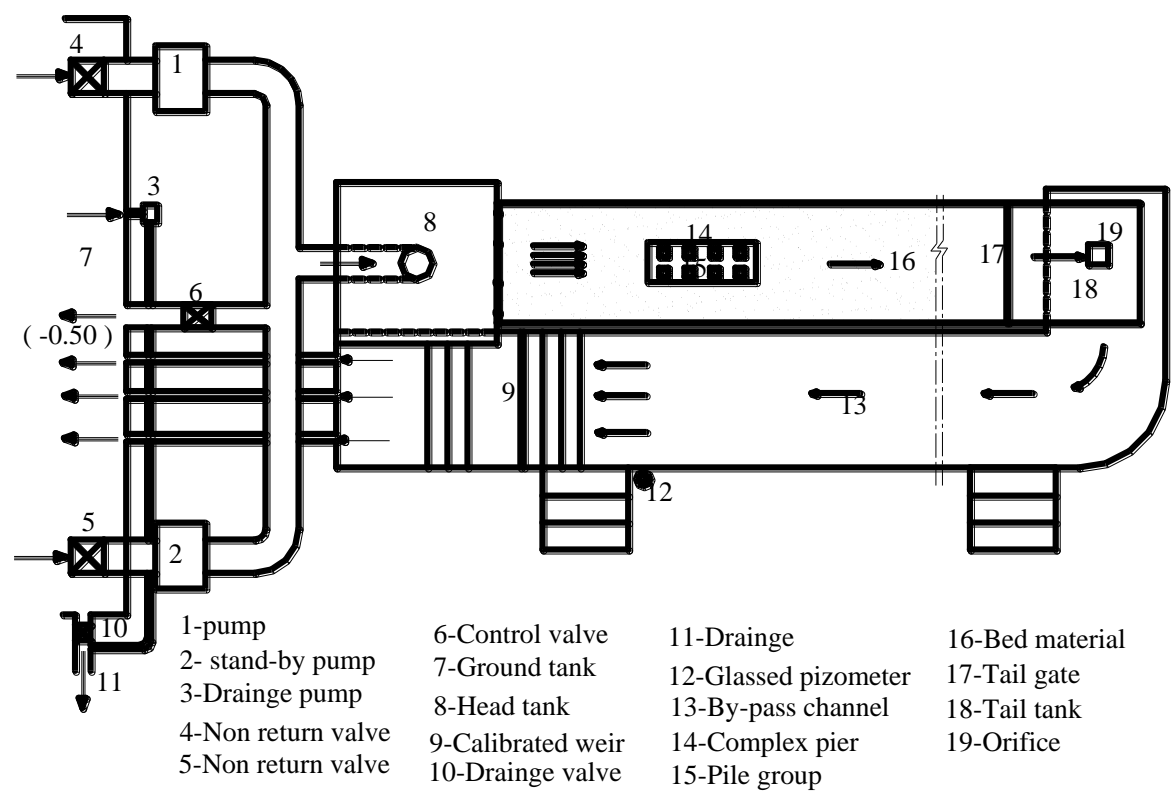

Fig (2): Schematics of the flume and related facilities

\section{EXPERIMENTAL APPROACH}

In this study, One hundred and fifty six runs were conducted and were categorized into three sets of a rectangular pile cap, (a Square nose, round nose, and sharp nose). For each set of experimental work, the discharge of $17.6 \mathrm{l} / \mathrm{s}$ was kept constant for all 
runs and four values of water depth were used (Y= 15.0, 13.0, 11.0, and $9.0 \mathrm{~cm}$ ), Table 1. Five submergence ratios (the ratio of the submerged depth of the pile cap to the water depth, $\left.\mathrm{d}_{\mathrm{su}} / \mathrm{Y}\right)$ of $\left(\mathrm{S}_{\mathrm{r}}=0.00\right.$, $0.25,0.50,0.75$ and 1.00$)$ and three different skew angles (angle of attack) of complex pier with the main flow direction, $\left(\alpha=0.0,10.0\right.$ and $\left.20.0^{\circ}\right)$ were considered, for each set, see Fig. (3) and Table 1.

Table (1): Flow conditions for the tested models

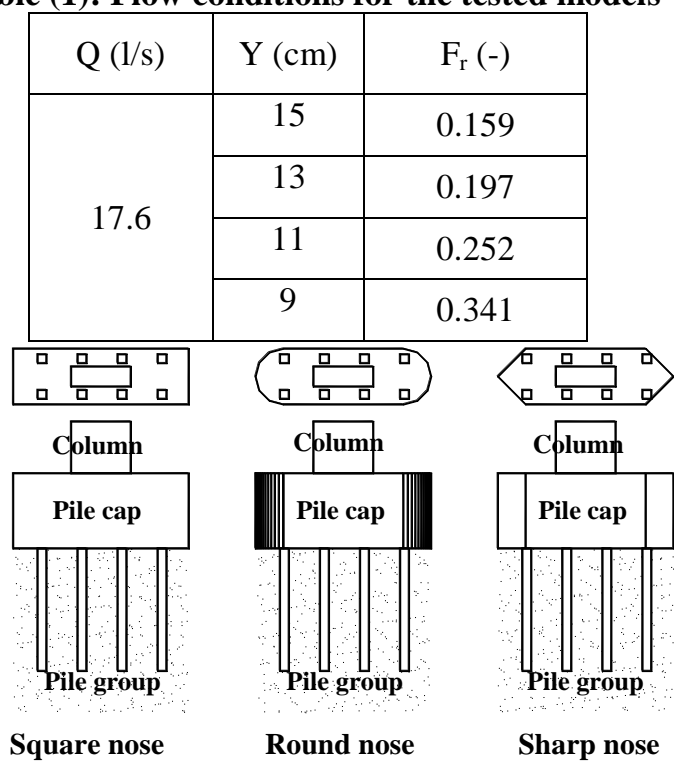

\section{EXPERIMENTAL PROCEDURES}

Fig (3): Complex pier configuration

depth of the pile cap to the water depth, $d_{\mathrm{su}} / \mathrm{Y}, \alpha$ is the skew angle of the pile cap (angle of attack) and $\eta$ is a factor depends on the pile cap shape.

Figure (4) illustrates the relationships between the values of $D_{s} / Y$ and the values of $F_{r}$ for different submergence ratio, $S_{\mathrm{r}}$, complex pier skew angle, $\alpha$, and pile cap shape. It was clear that increasing the values of $F_{r}$ led to increase $D_{s} / Y$. Decreasing the values of $F_{r}$ not only increases the water depth which resists the vortices but also decreases the velocity lowers than the critical velocity of the bed material which decreases the scouring process. It was apparent that, increasing the values of submergence ratio of pile cap, $S_{r}$, increases the values of $D_{s} / Y$. This is due to increasing $S_{\mathrm{r}}$ led to decrease water cross-sectional area consequently increasing velocity which increases the scour process. Also the case of no submergence ratio, $S_{r}=0.0$, gives the minimum values of relative scour depth, consequently this is the ideal and preferable case from the scour point of view.

It was clear that, increasing complex pier skew angle, $\alpha$, increases the relative scour depth, $D_{\mathrm{s}} / Y$, due to the same reason of decreasing the water crosssectional area and increasing the striking area which
For each run, after the flume was filled with the bed material and accurately leveled, the shape, the submergence ratio and the skew angle of the considered pile cap were adapted. The tail gate was completely closed and the backwater feeding is started first until its depth reaches higher than the required water depth, and then, the upstream feeding is pumped. To adjust the water depth, the tail gate is tilted gradually. For each run, when the required water depth is adjusted and after reaching the equilibrium flow conditions, the running time of the test was started. Each test was run for 4 hours, which were sufficient for most of the tests to reach a quasi equilibrium state of scour. The measurements consisted of scour geometry. After the running time, the run was stopped and the flume was drained, then the scour hole geometry was recorded with a précis point gauge.

\section{EXPERIMENTAL RESULTS AND ANALYSIS}

From the dimensional analysis, any length of the geometry of the scour hole denoted by, L, can be written as:

$$
\frac{\mathrm{L}}{\mathrm{Y}}=\phi\left(\mathrm{F}_{\mathrm{r}}, \mathrm{S}_{\mathrm{r}}, \alpha, \eta\right)
$$

Where: $\mathrm{Y}$ is the water depth, $\mathrm{F}_{\mathrm{r}}$ is Froude number calculated at the location which water depth, $\mathrm{Y}$, was measured, $S_{r}$ is the submergence ratio of the pile cap which equals to the ratio of the submerged induce the scouring vortices. Also, the effect of the valuese of $S_{r}$ on the values of $D_{s} / Y$ is more significant for the higher values of complex pier skew angle than that those of the smaller values. From Fig. (4) one can see that, the effect of the values of $S_{r}$ on the values of $D_{s} / Y$ is more significant for the case of rectangular complex pier with square nose than for the case of rectangular complex pier with sharp nose. Moreover the effect of the values of $S_{r}$ on the values of $D_{s} / Y$ is more significant for the case of rectangular complex pier with sharp nose than for the case of rectangular complex pier with round nose. Finally, although the rectangular complex pier with round nose gave the smallest values of the relative scour depth, $D_{\mathrm{s}} / \mathrm{Y}$, Rectangular pile cap with sharp nose of complex pier gave closed results to it.

Figure (5) clarifies the relationships between the values of $\mathrm{L}_{\mathrm{s}} / \mathrm{Y}$ and the values of $\mathrm{F}_{\mathrm{r}}$ for different submergence ratio, $S_{r}$, complex pier skew angle, $\alpha$, and pile cap shape. It was obvious that, increasig the values of $F_{r}$ increases the values of $L_{S} / Y$. Decreasing the values of $F_{r}$ leads to decrease the velocity lower than the critical velocity of the bed material which decreases the scouring process. It was clear that, increasing the submergence ratio of the pile cap increases the values of relative scour length, $\mathrm{L}_{\mathrm{s}} / \mathrm{Y}$, 
Also the case of no submergence ratio, $S_{\mathrm{r}}=0.0$, gives the minimum values of relative scour length, consequently this is the ideal and preferable case from scour point of view. Figure (5) shows that, increasing the values of complex pier skew angle, $\alpha$, increases the values of relative scour length, $\mathrm{L}_{\mathrm{s}} / \mathrm{Y}$. For $\alpha=0^{\circ}$ the effect of submergance ratio, $S_{\mathrm{r}}$, has small effect on the relative scour length, $\mathrm{L}_{\mathrm{s}} / \mathrm{Y}$, this effect increased to become maximum effect at $\alpha=10^{\circ}$ and decreased again with $\alpha=20^{\circ}$ but still higher than that of $\alpha=0^{\circ}$.

It was obvious that, the effect of the values of pile cap submergence ratio, $\mathrm{S}_{\mathrm{r}}$, on the values of $\mathrm{L}_{\mathrm{s}} / \mathrm{Y}$ is more significant for the case of rectangular complex pier with square nose than for the case of rectangular complex pier with sharp nose which has effect of the values of $S_{\mathrm{r}}$ on the values of $\mathrm{L}_{\mathrm{s}} / \mathrm{Y}$ is greater than the case of rectangular complex pier with round nose. Finally, although the rectangular complex pier with round nose give the smallest values of the relative scour length, $\mathrm{L}_{\mathrm{s}} / \mathrm{Y}$, Rectangular pile cap with sharp nose of complex pier gave closed results to it.

\section{EVALUATION OF SCOUR HOLE PARAMETERS}

The maximum scour depth and scour hole length are important design factors. Based on the experimental data, the statistical methods (regression analysis) were used with several models for developing the following empirical formulae,

data, which are valid for the range of the obtained experimental data:

1. Increasing Froude number leads to increase the maximum scour depth and length around complex bridge pier.

2. Increasing submergence ratio of pile cap leads to increase the maximum scour depth and length around complex bridge pier.

3. From the scour point of view, the case of no submergence ratio is the ideal case. It is
$\frac{D_{s}}{Y}=2.975 F_{r}+0.204 S_{r}+0.007 \alpha+0.157 \eta-0.612$

$\frac{L_{s}}{Y}=\exp \left(6.77 F_{r}+0.714 S_{r}+0.0329 \alpha+0.279 \eta-1.42\right)$

Where: $\eta$ is the pile cap shape factor which was chosen according to the regression analysis, $\eta=1.5$ in case of rectangular pile cap with square nose

$\eta=1.0$ in case of rectangular pile cap with sharp nose

$\eta=0.67$ in case of rectangular pile cap with round nose

Eqs. 1 and 2 are valid for the tested conditions with correlation $\mathrm{R}^{2}$ equal to 0.926 and 0.90 , respectively. It should be noticed that, $75 \%$ of the experimental results were used to develop the empirical formulae, while the rest of experimental data about $25 \%$ were used to validate the empirical formulae. Figures $(6,7)$ represent comparison between the measured and the computed relative scour depth and length. Also, it can be clarified that, the computed data agree well with the measured ones.

\section{CONCLUSIONS}

In summary, the following conclusions were made based on the analysis of the experimental

preferable case to be applied when complex bridge pier is constructed.

4. Increasing skew angle of complex bridge pier leads to increase the maximum scour depth and length around complex bridge pier.

5. The rectangular pile cap with round nose is more effective in decreasing the maximum scour depth and length but the rectangular pile cap with sharp nose gave closed results to it. 
Esam Eldeen Y. Helal " Effect Of Submergence Ratio Of Pile Cap, ...."
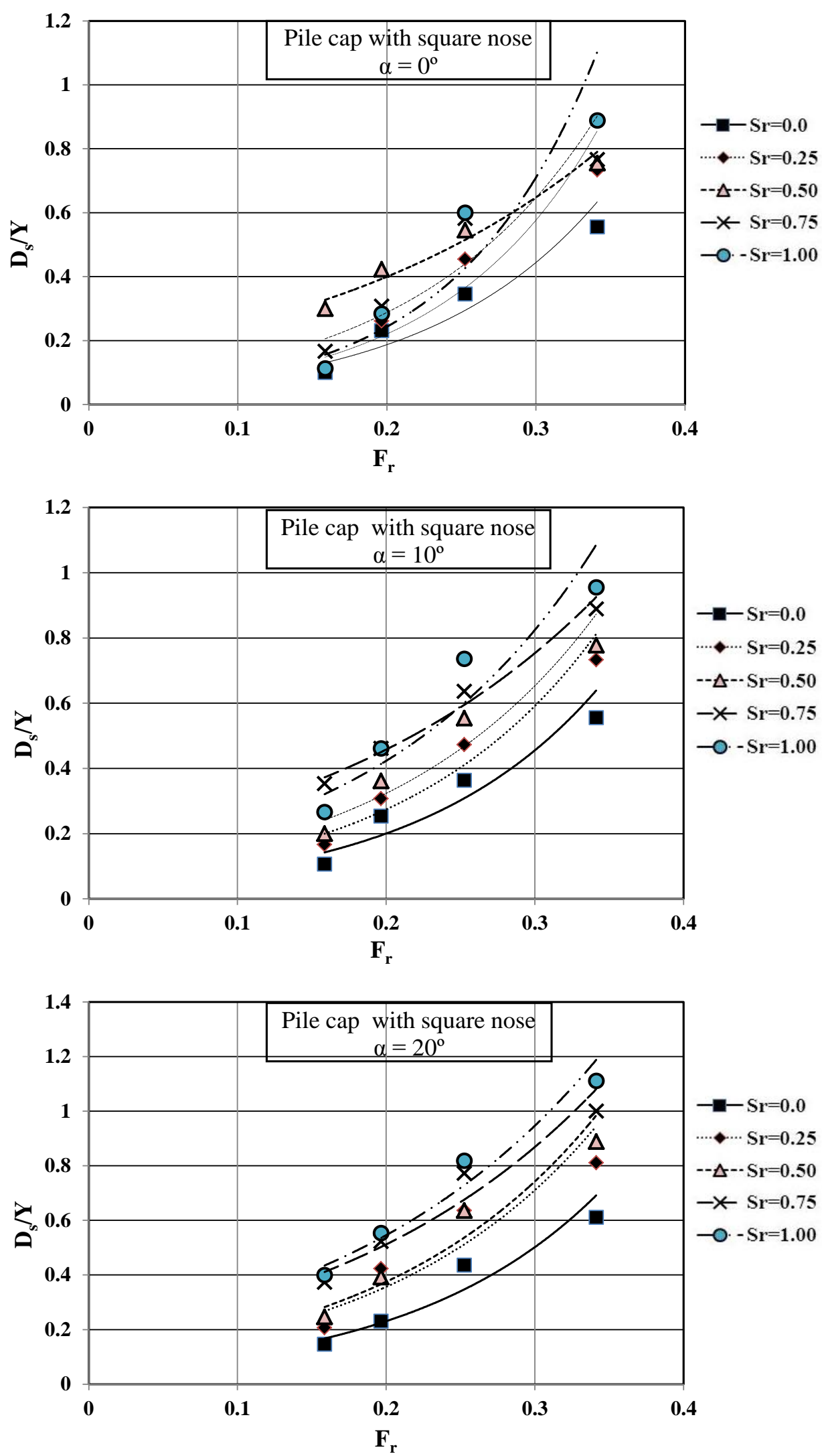

Fig. (4) Relationship between $D_{s} / Y$ and $F_{r}$ for different pile cap submergence ratios, skew angles, and shapes. 
Esam Eldeen Y. Helal " Effect Of Submergence Ratio Of Pile Cap, ...."
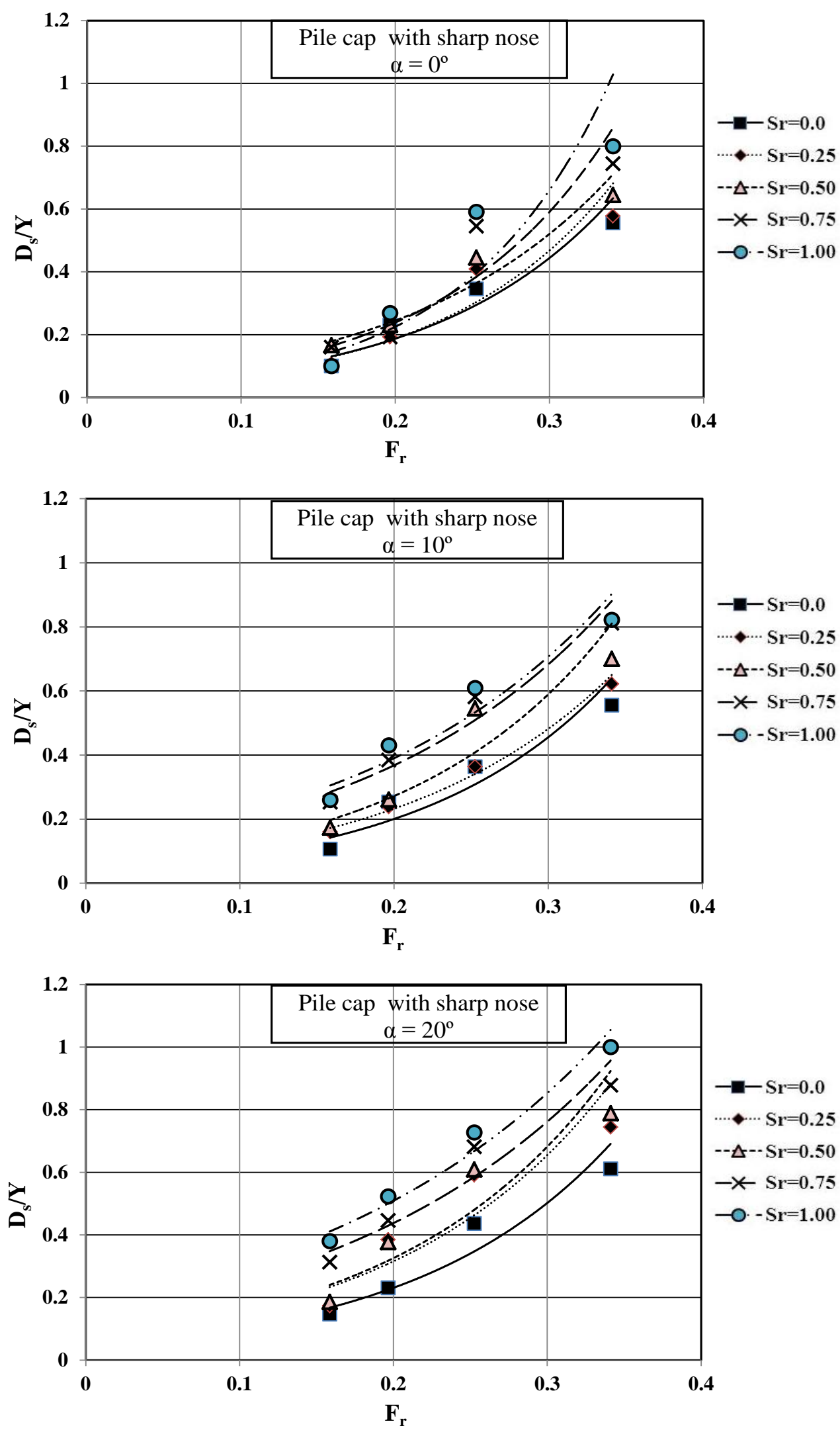

Fig. (4) Continue 
Esam Eldeen Y. Helal " Effect Of Submergence Ratio Of Pile Cap, ...."
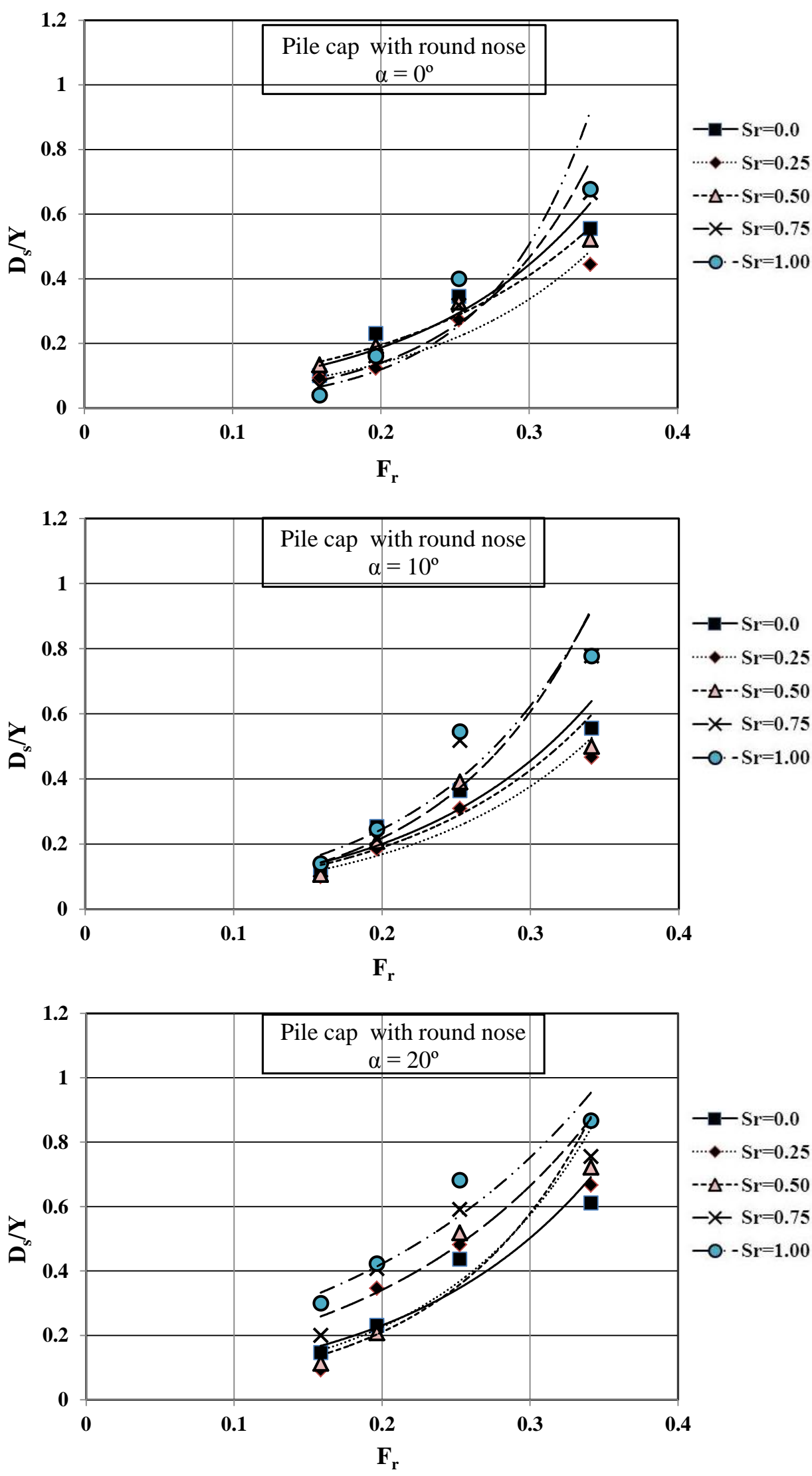

Fig. (4) Continue 
Esam Eldeen Y. Helal " Effect Of Submergence Ratio Of Pile Cap, ...."
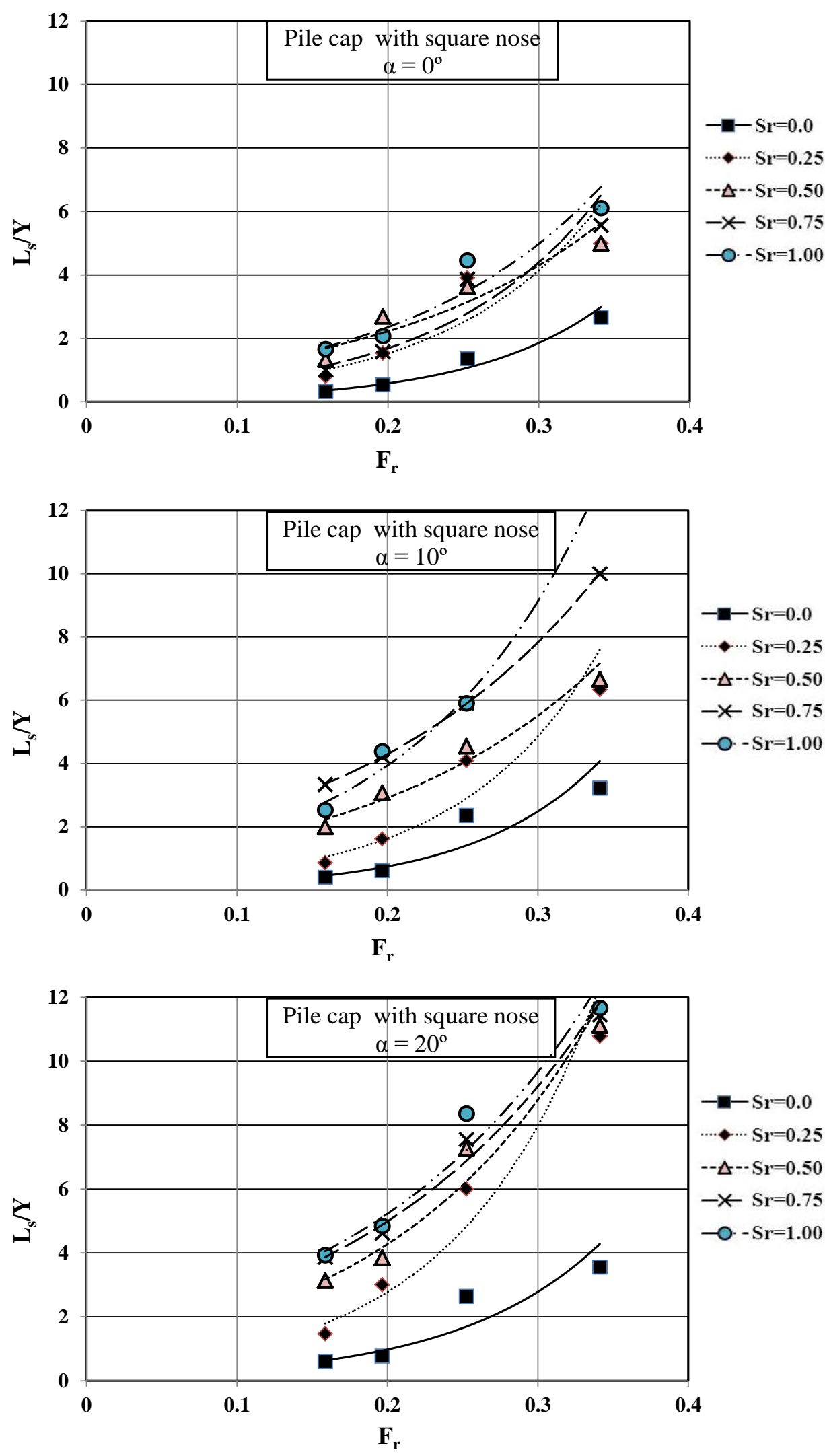

Fig. (5) Relationship between $L_{s} / Y$ and $F_{r}$ for different pile cap submergence ratios, skew angles, and shapes. 
Esam Eldeen Y. Helal " Effect Of Submergence Ratio Of Pile Cap, ...."
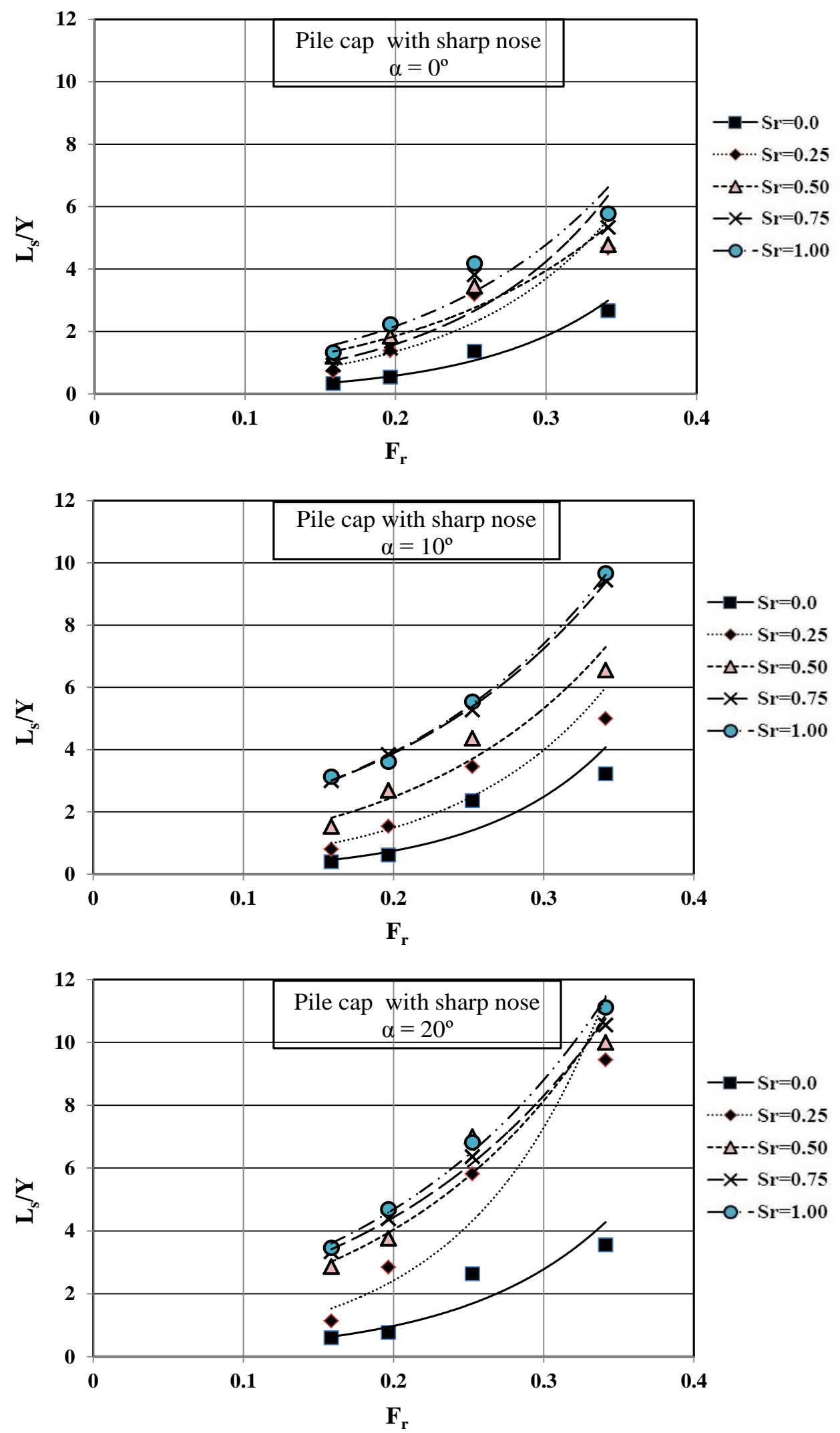

Fig. (5) Continue 
Esam Eldeen Y. Helal " Effect Of Submergence Ratio Of Pile Cap, ...."
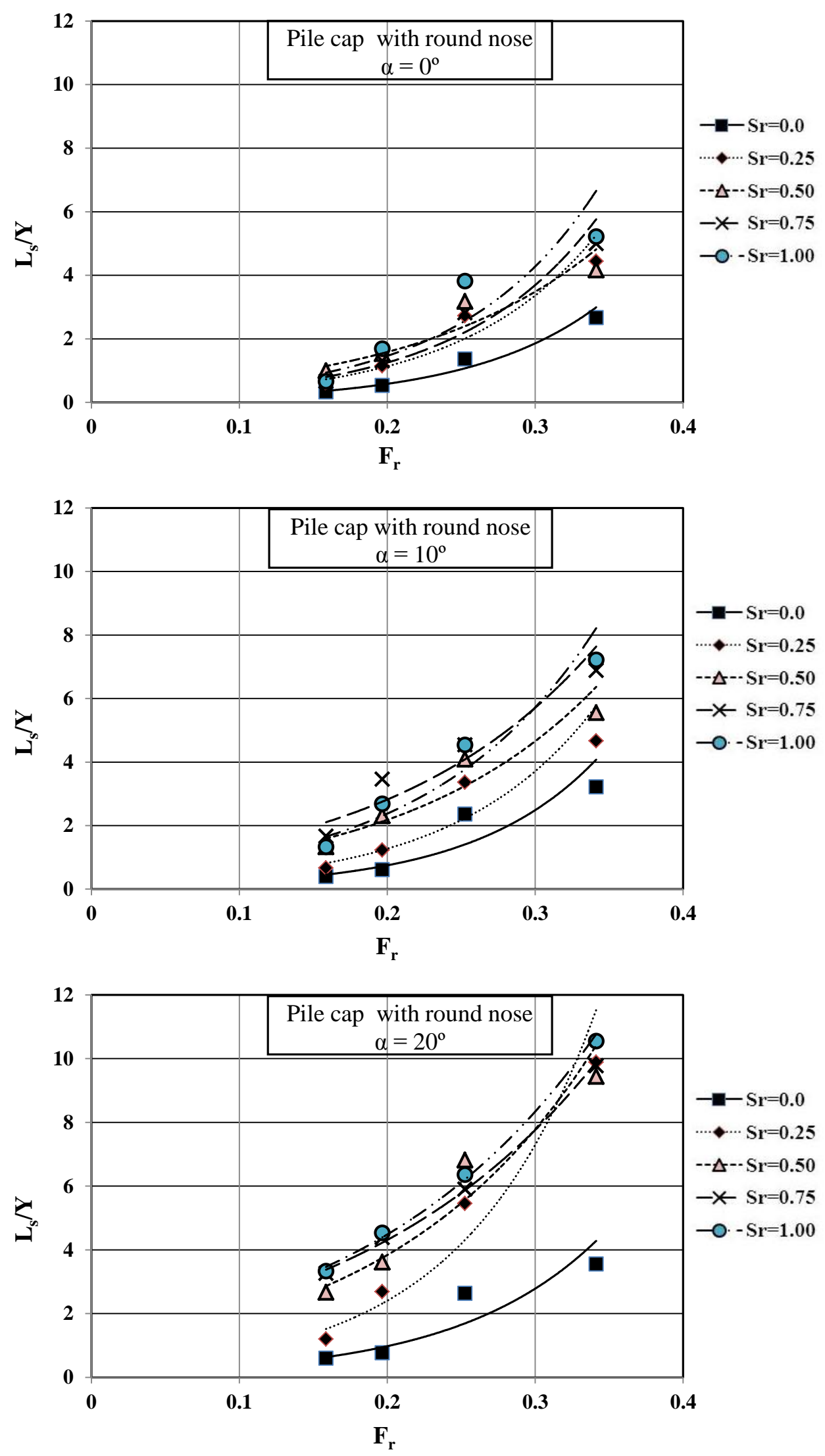

Fig. (5) Continue 


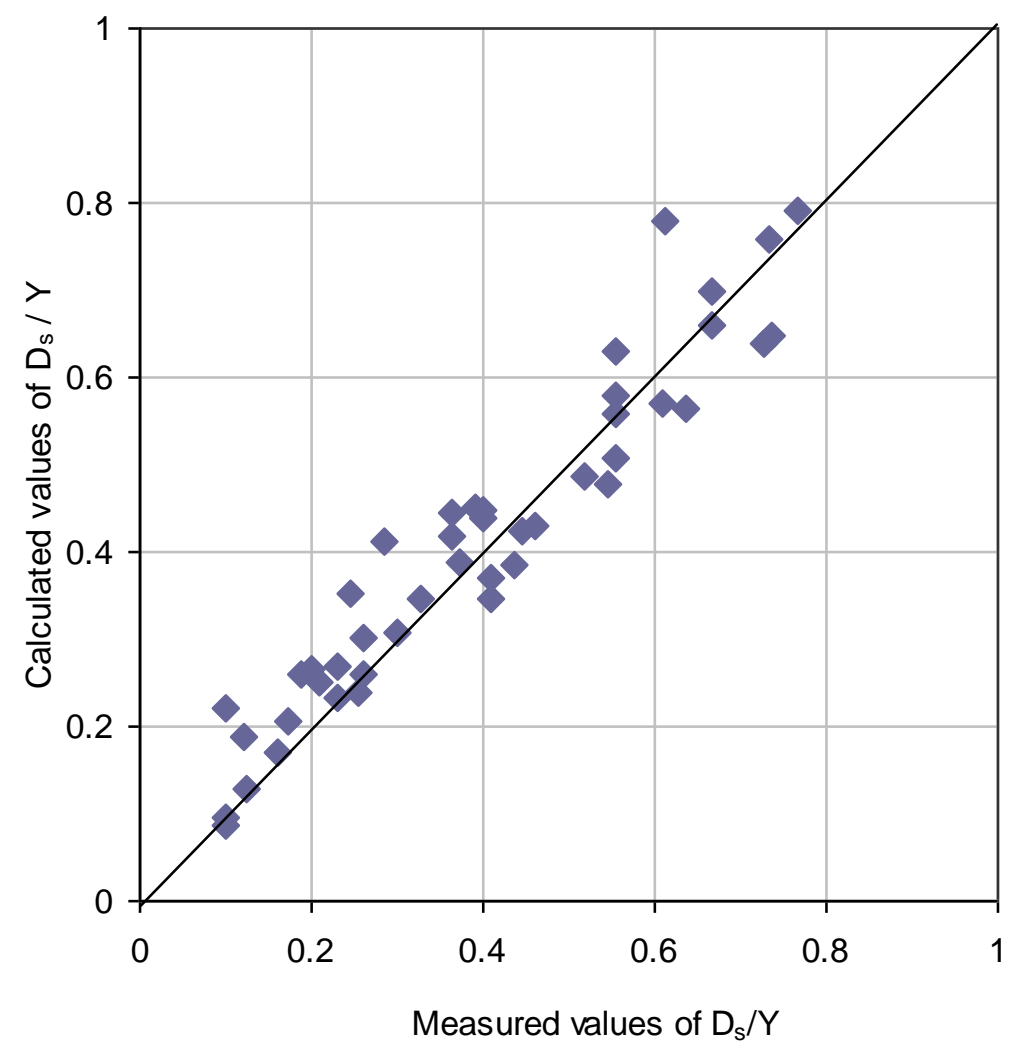

Fig. (6) Comparison between measured and calculated values of $D_{s} / Y$

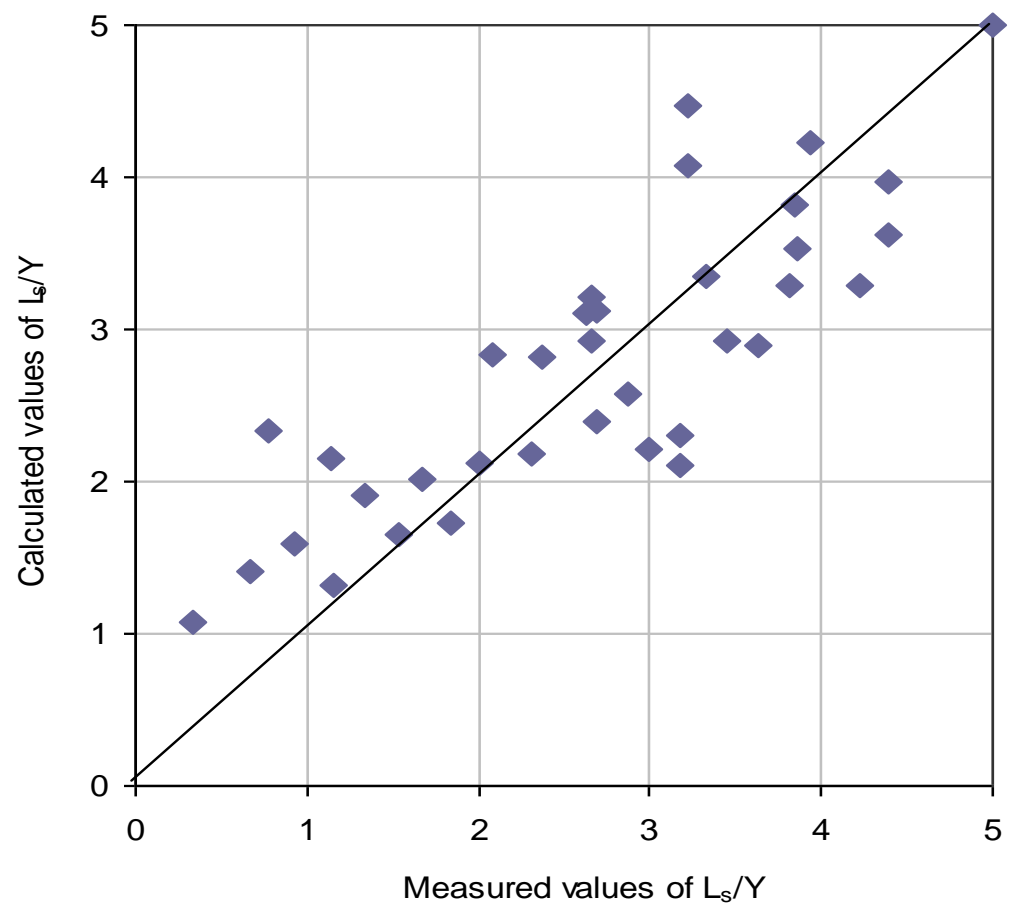

Fig. (7) Comparison between measured and calculated values of $L_{s} / Y$ 


\section{REFERENCES}

[1] Amini, A. S., Mohammad, A. T., Aziz, A. A., Ghazali, H. A., Haut, K. B., (2010). "A local scour prediction method for pile caps in complex piers" water management volume 164 issue WM2.

[2] Ashtiani .A.B and Beheshti. A.a (2006) "Experimental investigation of clear-water local scour at pile groups" ASCE, 132, pp. 11001104.

[3] Baker, C.J. (1983). "New design equation for scour around bridge piers" Journal of Hydraulic Division, ASCE., Vol. 109, No. 5, pp. 767-767

[4] Cherties c., Teixeira L., Simarro G., (2012). "Influence of flow conditions on scour hole shape for pier groups" water management volume 165 issue WM1.

[5] Coleman, S.E. and Melville, B.W. (2001). "Case study: New Zeeland Bridge scour experiences" Journal of Hydraulic Eng., ASCE, Vol. 127, No. 7, pp. 535-546

[6] Coleman, S.E. (2005). "Clear-water local scour at complex piers" Technical note Journal of Hydraulic Eng., ASCE, Vol. 131, No. 4, pp.330334.

[7] Dey, S., Bose, S.K. and Sastry, G. L.N. (1995). "Clear-water scour at circular piers" a model, ASC, J. of Hydraulic Eng., 121(12), pp.869-876.

[8] Ettema, R. (1980) "Scour at bridge piers" Report No. 216, School of Eng., University of Auckland, Auckland, New Zealand.

[9] Ferraro, D., Tafarojnoruz, A., Gaudio, R., and Cardoso, A. H. (2013). "Effects of pile cap thickness on the maximum scour depth at a complex pier" Journal of Hydraulic Engineering, ASCE, Vol. 139, No. 5, pp. 482-491.

[10] Hannah, C. R. (1978). "Scour at pile groups." Research Rep. No. 28-3, Civil Engineering Dept., Univ. of Canterbury, Christchurch, New Zealand.

[11] Melville, B.W. (1992). "Local scour at bridge abutment" journal of Hydraulic Eng., ASCE, Vol.118, No. 4, pp. 615-631.

[12] Melville, B.W. and Sutherland, A.J. (1988) "Design method for local scour at bridge piers" Journal of Hydraulic Eng., ASCE, Vol.114, pp.1210-1226.

[13] Richardson, E. V., and Davis, S. R. (2001). "Evaluating scour at bridges." Hydraulic Engineering Circular No. 18 (HEC-18), Rep. No. FHwA NHI 01-001, Federal Highway Administration, Washington, D.C

[14] Richardson E.V. and Davis S.R. (2001) HEC-18. "Evaluating scour at bridges", Fedral Highway Administration, Washington DC., Technical report No. NHI 01-001.

[15] Salim, M., and Jones, J.S.(1996). "Scour around Exposed Pile Foundations", Compilation of Conference Scour Papers (1991-1998) ASCE, Reston, VA, pp. 335-346

[16] Sheppard, D., Odeh, M., and Glasser, T. (2004). "Large scale clear-water local pier scour experiments" J. Hydraulic. Eng., Vol 130, No.10, pp. 957-963.

[17] Sumer, B. M. Fredsoe, J.and Christiansen, N. (1992). "Time scale of scour around a vertical pile" in Proc. 2nd Int. Offshore and Polar Engineering Conference., Vol. 3, San Francisco, C. A., pp.308-315.

[18] Sumer, B.M., and Fredsoe, J.(1998). "Wave Scour around Group of Vertical Piles" Journal of Waterway, Port, Coastal, and Ocean Engineering, ASCE, Vol. 124, No. 5, pp. 248256.

[19] Sumer, M.B., and Fredsoe, J. (2001). "Scour around Pile in Combined Waves and Current" Journal of Hydraulic Eng. ASCE, Vol. 127, No.5, pp. 403-411.

\section{NOTATION}

$\mathrm{D}_{\mathrm{s}} \quad$ Maximum scour depth,

$\mathrm{D}_{50} \quad$ Median size of bed material,

$\mathrm{d}_{\mathrm{su}} \quad$ Submergence depth of pile cap

$\mathrm{F}_{\mathrm{r}} \quad$ Tail Froude number,

$\mathrm{L}_{\mathrm{s}} \quad$ Scour hole length in flow direction,

Q Channel discharge,

$\mathrm{S}_{\mathrm{r}} \quad$ Submergence ratio of pile cap, $=\mathrm{d}_{\mathrm{su}} / \mathrm{Y}$,

Y Water depth,

$\sigma \quad$ Standard deviation of bed material, and

$\alpha \quad$ Skew angle of complex pier. 